\title{
An Analysis of Eastern Objective Soteriology
}

«Theological Reflections»

2013. Vol. \#14. Pp. 66-90

Igor ZELENY, L'viv - Borislav, Ukraine

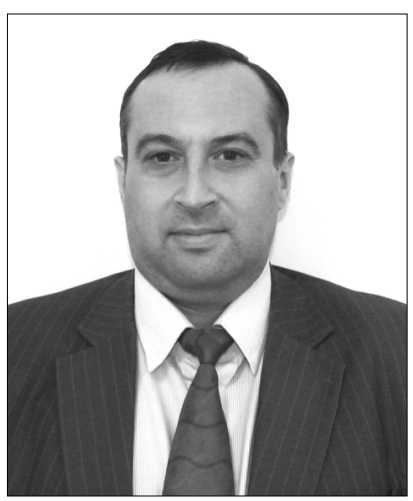

Igor Zeleny graduated from Ukrainian Baptist Theological Seminary (L'vivBorislav, Ukraine) in 2007 with a Master degree. Since the fall of 2007, he works at the UBTS and teaches the courses on systematic and historical theology for Bachelor degree programs. He holds an academic dean position at the UBTS since 2009. His main interests are systematic and historical theology, Orthodox theology, and in particular, Eastern Objective Soteriology, in which he teaches a course at the UBTS. Email: igorzeleny@gmail.com.

\section{Soteriology: Two ways of development}

Aready during the first centuries of Christianity, objective ally in the history of dogmatics they are referred to as the Eastern and Western positions on the teaching of salvation.

The first view may be termed "ontological proper." It is typical of classic Greek philosophy with its desire to grasp the essence of things. Over time Eastern theology began to develop from this point, with its accent on the apaphatic ("negative") way of knowing God, as well as its inclination toward the ontological (organic) theory of salvation.

The second way is more practical in its explanation of the world. It is typical for the Roman West with its systematized thinking framed by strict laws. It is not surprising that Romans treated Greeks in a condescending manner for their love of abstract discourse disconnected from real needs and, therefore, lacking in practical usefulness. ${ }^{[1]}$ Gradually in Western theology this way of thinking developed into the socalled juridical theory of salvation. The West is more inclined to understand God and His works in a cataphatic ("affirmative") way, and it is from here that the desire comes to give a "rational" (later-juridical) explanation of Christ's salvation. ${ }^{[2]} \mathrm{P}$. Parente notes:

${ }^{[1]}$ In his book The City of God, Augustine writes, “... as Tullius points out, their tendency to long discourses since olden times makes the Greeks more passionate lovers of debates than of the truth," (O grade Bozhiem, [Moscow: ACT, 2000], p. 417).

${ }^{[2]}$ The Reformation as the organic creation of the West has modified the Western model of soteriology, though in its main characteristics it has remained within the framework of a juridical interpretation of Christ's work. (Author's observation). 
...two soteriological motifs ... appear in the patristic tradition: one comes from John the Evangelist, and makes Redemption the exaltation of humanity to a living unity with God.., and it restores the image of God in us... The perspective of the Eastern Church fathers is based on incarnation, which by itself transforms the situation of fallen humankind because it brings God into human history and joins man to Christ the Savior, thus deifying him. On the other hand, the teaching of the Western fathers concentrates on the sufferings and death of Christ Who has sacrificed Himself in order to meet the requirements of God's justice and love, which was offended by Adam's $\sin . .$. as we see in Paul's theology... It is from here that the dominant idea of Sacrifice comes. ${ }^{[3]}$

The Scriptures contain both approaches in embryo. They can be found mainly in the apostolic epistles as well as in the writings of the church fathers:

While the Eastern fathers prefer to choose the first approach, the Western ones are glad to develop the second. But both are understandable without any exclusivism; in fact, both of them often overlap in the works of the same author. ${ }^{[4]}$

In our opinion, these two developments are not contradictory. Probably it is because of the mentality or the natural intellectual preferences of the Christian East and West that they concentrated their attention on those aspects of biblical teaching on salvation that were more attractive to them and, therefore, more understandable and significant. Gradually, this has led to a noticeable difference in their views, and, probably, to a specific doctrinal bent. (The specific one-sidedness of a doctrine is the result of emphasis on particular elements of a teaching instead of on the truth as a whole.) It is from here that the familiar opposition of these two theological positions begins, and, to some degree, the accent placed on their supposed total contradiction, and categorical statements to the effect that it is impossible to follow both views at the same time, and that in one's theological studies it is necessary to «mutually exclude» them. However, as Hegel states, only what is whole is true. This must be kept in mind when we study the evidence of both of sides which, at times, are trying if not to ignore or reject the opposite point of view as false, then at least, to minimize its influence or biblical significance.

\section{Definition of Eastern soteriology}

Donald Fairbairn defines the Eastern theory of salvation as the classical one. ${ }^{[5]}$ Most likely, in this way he is trying to stress the ancient origin of the Eastern soteriological position. However, in our opinion, the juridical theory of salvation on the whole may also be defined as a "classical" one, since juridical motifs are also noticeable in the works of the Eastern fathers, and the followers of the Eastern view admit it. In fact, the church fathers did not draw a strict line between these two different interpretations of the work of Christ: for them the juridical and the ontological views were, instead, different sides of one soteriological picture.

${ }^{[3]}$ P. Parente, Bogoslov'ia Khrista, trans. from Italian (L'viv: Vydavnytstvo "Strim," 1995), p. 475 . 
In this article the definition of Eastern soteriology will be based on two ideas. Consequently, the Eastern soteriological position is:

Ontological - it explains the essence of the work of Christ on the ontological (being) level, that is, what Christ has done with our essence, with the collective human nature (how human nature was freed from the presence of sin itself).

Organic - it examines the nature of humanity as a collective united organism (from Adam to Christ and to the last man), where Christ became a part of humanity, and where our salvation was completed. ${ }^{[6]}$

\section{Main points:}

- The East is more disposed to interpret sin as a corruption, an illness. Therefore, if something is ill, it should not be destroyed but cured. To restore creation that was corrupted by sin, the Creator-Word Himself assumes its nature with all the consequences of the sin of Adam; He then eliminates corruption by His death, and restores the original creation in resurrection.

- At the time of the crucifixion Christ took upon Himself not only the guilt for sin (juridical understanding), but by the very fact that He took upon Himself the corrupted nature, i.e. from birth, He accepted all the consequences of the Fall (sickness, hardship, weariness) but without personal sin.

- By restoring in Himself the originally created image of man through His death and resurrection, the Savior once again opens for humankind the way to its eternal destination - to deification, i.e. the attainment of the image of God. Now everyone can embark on this way and receive grace and power from God, thanks to the organic, synergic connection in the Body of the Church.

Generally, ontological theory becomes definitive for theologians of the Eastern Church from the time of Irenaeus of Lyons (second century) onwards.

\section{Development of doctrine}

The limitations of this article allow us to present only a generalized summary of this soteriological position.

1. The first appearance of the organic view may be seen already in the works of the second century apologists. However, Justin Martyr, the first major apologist of the second century, does not develop these soteriological truths extensively. He mostly covers apologetic themes and gives little attention to soteriological issues as such. Though even in Justin we can see (in embryo) ideas about the restoration of creation in the Word, and the organic unity of humanity with Christ:

${ }^{[4]}$ Ibid.

${ }^{[5]}$ Donald M. Fairbairn, Inymi glazami. Vzgliad evangel'skogo khristianina na Vostochnoe pravoslavie (Donetsk, 2003), p. 281.

${ }^{[6]}$ Note that in this article the following terms will be used to describe Eastern soteriology: organism in the sense of ontological-organic theology and organicists are followers of this view. The writer does not claim any theological "creation" of new forms or expressions; however, in view of the poverty of evangelical terminology in this area of study, these neologisms will be used as functional terms. Consequently, to describe juridical thinking (by way of analogy) 
This was taught to us by Jesus Christ, the only Son, born of God, His Word and the first-born and the power, Who, according to His will, was made man for the transformation and restoration of the human race... We are taught that Christ is the first-born of God and we have stated above that He is the Word in which all of humanity takes part. ${ }^{[7]}$

Nevertheless, in view of the apologetic focus of his writings, Justin practically does not go beyond simple affirmation (more in the juridical sense) of the indisputable truths concerning the soteriological work of Christ:

...Christ has redeemed us, burdened with the heaviest of sins that we have committed ourselves, through His crucifixion on the tree... It pleased the Father that His Christ would take upon Himself the condemnation of all, for the whole human race, knowing that He would resurrect the One who was crucified and died... ${ }^{[8]}$

However, starting with Irenaeus of Lyons (second half of the second century), Eastern theologians considered Christ's incarnation the indispensable condition for the correction of human nature. Irenaeus is the first in a line of Eastern theologians who give a detailed discussion of the subject of salvation. It is in his works that we trace the main characteristics of what will be called Eastern organic soteriology in the future. According to it, the Creator (the Word) was incarnated in order to correct in Himself the original corruption of Adam:

... He restored the ancient creation (man) in Himself. For just as by the disobedience of one man sin entered and through sin death appeared, so by the obedience of one man righteousness was introduced and made human life fruitful which was formerly dead (Rom. 5:19)... He Himself the Word, restoring Adam in Himself rightfully received birth for the restoration of Adam from Mary, Who was yet a virgin... In order that there would be no other creation, and that creation was no other which demanded salvation, but in order that the very same (Adam) be restored, with regard to his resemblance in origin. ${ }^{[9]}$

It may be assumed that the Eastern concept of the deification of humanity (human nature) by the power of the incarnate Word begins with Irenaeus. In Irenaeus we find the famous phrase, "The Son of God became man so that men might become sons of God," which was repeated by Athanasius and other Eastern theologians:

For this reason the Word of God became man and the Son of God-the Son of Man, in order that (Man) would be united with the Son of God and, receiving adoption, would become a Son of God. For we could never receive incorruption and immortality if we were not joined with incorruption and immortality. But how could we be united with incorruption and immortality if incorruption and immortality were not previously made to be such as we are, so that the corruptible could be swallowed up in incorruption and mortality by immortality, so that we might receive adoption? ${ }^{\text {[10] }}$

the terms juridicism and juridicists will be used.

[7] Justin Martyr, "Pervaia apologiia," in Tvoreniia, Biblioteka otsov $i$ uchitelei tserkvi (Moscow: Palomnik, Blagovest, 1996), section 23, 46, pp. 54, 76; author's italics.

${ }^{[8]}$ Ibid., "Razgovor s Trifonom iudeem," 86, 95, pp. 276, 289.
${ }^{[9]}$ Irenaeus of Lyons, "Protiv eresei, tret'ia kniga," in Tvoreniia, Biblioteka otsov i uchitelei tserkvi (Moscow: Palomnik, Blagovest, 1996), section 21. 10, pp. 303, 304, author's italics.

${ }^{[10]}$ Irenaeus of Lyons, "Protiv eresei, tret'ia kniga," in Tvoreniia, Biblioteka otsov $i$ uchitelei tserkvi (Moscow: Palomnik, Blagovest, 1996), section 21. 10, pp. 303, 304, author's italics. 
Irenaeus may be considered the originator of the theory of recapitulation or anacephaleosis, the teaching about Christ's restoration in Himself of Adam's nature. For all that the dominant tendency in Irenaeus is toward this explanation, we may also trace in his writings the juridical aspect of the work of Christ (according to Paul's teaching):

... the mighty Word and true Man, intentionally redeeming us by His blood, gave Himself in redemption for those in captivity... the Word of God is almighty, but unstinting in His righteousness, and righteously turned against rebellion and bought back [His] property from it, not by means of power, by which it (rebellion) overpowered us, greedily stealing away what did not belong to it, but by conviction, as is suitable for God, convincing, not forcing, what He wished, in such a way that righteousness would not be destroyed nor that the ancient creation of God would perish. And so, the Lord redeemed us by His blood and gave His soul for our souls and His flesh for our flesh and poured out the Spirit of the Father for the union and fellowship of God with man... ${ }^{[1]}$

A question arises: Can we say that the Eastern writers of the second century had already settled in favor of an organic understanding of the work of Christ? We suppose that such a statement would be a definite exaggeration. However, starting from Irenaeus the organic element does become more evident. In his polemics with the Gnostics Irenaeus continually emphasizes that Christ came to save the very nature of fallen Adam:

For, if He did not receive flesh from man, then He did not become man nor the Son of Man; and if He did not become what we were, then He did not do anything great in what he suffered and endured. Anyone would agree that we consist of a body taken from the earth and a soul that received its breath from God. Such became the Word of God, restoring His creation in Himself..$^{[2]}$

But it [righteous blood-author's note] would not be sought if it could not save; and the Lord would not restore it in Himself if He Himself did not become flesh and blood corresponding with the original creation, saving in Himself at the end that which at the beginning perished in Adam. ${ }^{[13]}$

In addition, Irenaeus, when making a distinction between the image and the likeness of humanity, points out that in Christ humans were given back the chance of achieving God-likeness:

For, although formerly it was said that man was created in the image of God, that was not shown (by the act itself), for the Word, according to the image of which man was created, was as yet invisible. Therefore he easily lost the likeness. When the Word of God became flesh, He confirmed the other, for He truly showed the image; He himself became that which was in His image, and firmly restored the likeness, making man like to the invisible God through the visible Word. ${ }^{[14]}$

2. Athanasius (fourth century), when fighting against the Arian heresy, advocated the idea that the Word became man in order to bring creation back to its original perfect

${ }^{[11]}$ Ibid., "Protiv eresei, piataia kniga," section 1.1, p. 446, 447; author's italics. Similar passages include Book 5, section 2, 1-2.

${ }^{[12]}$ Ibid., Book 3, section 22.1, p. 304; author's italics.
${ }^{[13]}$ Ibid., Book 5, section 14.1, p. 475; author's italics.

${ }^{[14]}$ Ibid., Book 5, section 16.2, pp. 480-481; author's italics. 
state. Only the Creator could (and had to) do such work, so as to restore His own creation by means of Himself. Athanasius repeats the concept of deification offered by Irenaeus:

For this reason the created and human body was accepted, in order to, as the Founder, renew that body, deify it in Himself, and thus bring all of us in the likeness of His body into the heavenly kingdom... and we would not be freed from sin and damnation if the flesh in which the Word was enfolded was not human in essence (for there would be nothing in common with us if the body were alien); thus humanity would not be deified if the One that became flesh was not in nature of one being with the Father, the true and actual Word of the Father. ${ }^{[15]}$

It [the Word] became human in order that we would become divine; it was revealed in the body so that we would attain the understanding of the invisible Father; It suffered curses from people so that we could inherit immortality. ${ }^{[16]}$

Athanasius develops Irenaeus' argumentation: If the Creator God did not become a man and did not correct in Himself Adam's nature corrupted by sin, then humanity would have no hope. If Christ is not God, then humanity has no connection with the life-giving power of God. If $\mathrm{He}$ is not man, then God did not gain access to humanity in Christ, and He therefore cannot regenerate it:

When man was created and necessity demanded the cure not for that which was not but for that which was already created; then the Physician and Savior had to approach that which was already created in order to heal what existed. Thus He became man and made use of the human instrument-the body. ${ }^{[17]}$

Athanasius points out the main reasons for Christ's incarnation: a) to restore human nature, removing its decay through the resurrection; b) to restore God's image in man through the appearance of the true image in God Himself, and through the teaching about God; c) to pay the debt of death for all and to bring a sacrifice in order to free humanity from the original transgression (the juridical element, although Athanasius understands the death of Christ somewhat in the organic sense, namely as the destruction of death by the body of Christ):

Concerning the reasons for His coming in the flesh, as far as possible according to the measure of the strength of our intellect it has been explained above; namely 1) to transform the corruptible into the incorruptible, which belonged to none other but to the Savior alone; and 2) to recreate the image of human beings [by the One Who] in the beginning created the universe out of nothing, which was characteristic of no one but the image of the Father, which 1) resurrects the mortal by means of immortality-which was characteristic of no one except the source of life-our Lord Jesus Christ, which 2) teaches about the Father, to nullify the service of idols, which belonged to none

${ }^{[15]}$ St. Athanasius of Alexandria, "Na Arian, Slovo vtoroe" in Tvoreniia, 4 vols., (Moscow: Izd. Sviato-Preobrazhenskogo Valaamskogo monastyria, 1994), vol. 2, section 70, p. 353; author's italics.

${ }^{[16]}$ St. Athanasius of Alexandria, "Slovo o ics voploshchenii Boga-Slova, 54" in Tvoreniia, 4 vols. (Moscow: Izd. Sviato-Preobrazhenskogo Valaamskogo monastyria, 1994), vol. 1, 54, p. 260; author's italics.

${ }^{[17]}$ Ibid., vol. 1, 44, pp. 247-248; author's ital- 
other than the Word that brought the universe into order, the one, only-begotten, true Son of the Father. 3) Inasmuch as, at last, the debt had to be paid that was laid upon all, because, according to what was said above, all had to die, which was the main reason for His coming: so that after He proved His divinity by deeds, to bring also, at last, a sacrifice for all, in place of all He put to death His own temple so as to make all free from responsibility for the ancient transgression, in Him, in His incorruptible body the beginning of the general resurrection has appeared, to prove that $\mathrm{He}$ is above death. ${ }^{[18]}$

The quotations above show that, in addition, Athanasius was not opposed to the juridical aspect of salvation though his primary attention was given to the fact of the incarnation of the Word. His focus on the restoration of the image in man gives support to future defenders of icon worship:

Since the image portrayed on the tree had become invisible because of external uncleanness, it was necessary to again approach the One whose image it was, so that the image on that substance could be renewed; because for the sake of the image portrayed, the very substance upon which it is portrayed is not rejected but renews the image upon it. In the same way the all-holy Son of the Father, as the image of the Father, came to our lands in order to renew man, created in that image, and to seek out the perishing by the removal of sins... ${ }^{[19]}$

3. The Cappadocian Fathers (fourth century) continued Athanasius' teaching (Basil the Great, Gregory of Nyssa, and Gregory of Nazianzus). In his teachings known as the Orations, Gregory of Nazianzus rejects Origen's idea about the work of Christ as a ransom to Satan, or even to God the Father Himself. He continues the teaching of Athanasius concerning the regeneration of human nature in Jesus, the return to the unity and wholeness of creation through deification:

...What took place is [of] God and received from Him (human nature), a unity of two opposites-flesh and Spirit, of which One deified and the other is deified. O, the new combination! O marvelous mixture! The Self-existent One begins being, the Uncreated creates, the Incomprehensible is comprehended through the rational soul that intercedes between Divinity and rude flesh; the Richest becomes a beggar-reduced to my flesh in order to make me rich by His Divinity; the One Who fulfills everything is starved out of His glory in order for me to partake of His fullness... I received the image of God and did not keep it: He took on my flesh in order both to save the image and make the flesh immortal. ${ }^{[20]}$

4. Soteriology of Augustine. Until the time of Augustine (...430) there were no Western writers who made any significant contributions or noteworthy changes to the paradigm of soteriological thought. True, the views of Augustine were mostly in other areas of theological interest:

${ }^{[18]}$ St. Athanasius of Alexandria, "Slovo o voploshchenii Boga-Slova, 20" in Tvoreniia, 4 vols. (Moscow: Izd. Sviato-Preobrazhenskogo Valaamskogo monastyria, 1994), vol. 1, 20, pp. 215-216 (author's italics and numeration).

${ }^{[19]}$ Ibid., vol. 1, "O voploshchenii Boga-Slova," 14, p. 208 (author's italics). By "tree" or "substance," Athanasius means the restoration of God's image in man's nature-but that opens up a new discussion about their literal understanding of icons.

${ }^{[20]}$ Gregory Nazianzus, "Slovo 45 Na sviatuiu Paskhu," in Sobranie tvorenii, 2 vols. (Moscow: ACT, 2000), vol. 1, p. 810; author's italics. 
In his principal course of thinking Augustine is far away from Greek theology. Both his suppositions and his conclusions are completely different. His main ideas are those of original sin, justification through grace, and peace with God though Christ's sacrifice. The new, Western type of thinking is confirmed and we find ourselves in the circle of the Apostle Paul's ideas. Man is viewed as subject to the wrath of God, and Christ's sacrifice is what pacifies this wrath and reconciles man with God.

Augustine did not arrange these ideas into a complete system... He does not make a sharp distinction between the juridical and renewing sides of redemption. Frequently, justification is based not on Christ's annihilation of the guilt for sin but on the sanctifying influence of the Holy Spirit. And again he sometimes teaches that though the redemption completed by Christ was the most appropriate way of salvation, God could have saved sinners some other way, thus making redemption only relatively essential. ${ }^{[21]}$

It is interesting to determine just what kind of vision - juridical or organic - Augustine held. In our opinion, one cannot agree with the interpretation that Augustine's views were predominantly juridical (as Western scholars like to say). On the whole, there is no clear distinction in his soteriological position, though one can already notice a definite tendency to the juridical position:

... God, giving blessing, having taken part in our human race, showed us the shortest way to take part in His divinity ${ }^{[22]}$ (organic vision).

...the blessed and true Intermediary showed that evil is sin, and not a substance or the nature of the flesh, because together with the human could it could be taken up and carried, and brought to death... although it was punishment for sin, but which, being sinless, he suffered for our sins ${ }^{[23]}$ (juridical).

...the living body that the first man had...; the same one that we have at present, but with a nature so changed and marred, which took place in him after he sinned... which Christ for our sake first condescended to take [upon Himself], although not of necessity but by His free will... He came down from heaven in order to put on the body of earthly mortality and to put on that body heavenly immortality ${ }^{[24]}$ (dual understanding).

For Augustine, Paul's teaching on justification by faith was critical. However, Augustine emphasized man's renewal by grace, which may be considered God's coworker in the transformation of human nature:

In nature there is only one Son of God, who, for our sake, mercifully became the Son of Man so that we, being by nature sons of men, could become sons of God by grace. For, remaining unchanged, He received our nature from us to receive us in it, and, while retaining His Divinity. became a partaker of our weakness, so that we, having changed for the better, would transform our mortal and sinful condition through fellowship with Him, the immortal and righteous, completing this good in the grace of His nature by the greater good. ${ }^{[25]}$

[21] L. Berkhov, Istoriia khristianskikh doktrin (St. Petersburg: Bibliia dlia vsekh, 2000), p. 188. ${ }^{[22]}$ Augustine, O grade Bozhiem, book 9, chapter 15 (Minsk: Harvest; Moscow: ACT, 2000), pp. 432-433.

Theological Reflections \#14, 2013
${ }^{[23]}$ Ibid., book 10, chapter 24, p. 486.

${ }^{[24]}$ Ibid., book 13, chapter 23, pp. 645-646.

${ }^{[25]}$ Ibid., book 21, section XV, p. 1175, author's italics. 
We see that such thoughts still fit with an ontological understanding of the work of Christ.

5. Crystallization of the ontological understanding of salvation. John of Damascus (eighth century) in the fourth part of his profound work The Sources of Knowledge, which is named An Exact Exposition of the Orthodox Faith, sums up the legacy of Eastern thought on soteriology in the following way:

...concerning the flesh of the Lord it is said that it is deified, that it became one with God and became God-not by means of application or transformation, or change, or a coming together of natures, as Gregory the Theologian [states] in [Word 45]: "One of the natures deified, the other was deified, and, I am bold to say, became one with God; and the One who anointed became a man and the anointed [became] God." Thus, one and the same flesh, in and of itself was mortal, but according to its person being joined with God the Word, was life-giving."[26]

And again John of Damascus lists two main - as he understands them-motivations for Christ's incarnation: 1) to restore human nature and the image of God in man; 2) to teach humanity through the appearance of God's perfect image in the God-man:

The Son of God became man in order to once again give man that for which $\mathrm{He}$ created him. For He created him in His image-intelligent and free and according to [His] image, that is, as perfect in virtue as is possible for a human being... But since the Son of God gave us the best and we retained it, therefore He [now] accepts the worstthat is, our being, in order to renew the image and likeness through Himself and in Himself, and also to teach us the virtuous life, accomplishing this through Himself which is easily attainable for us, to free us from decay by sharing life, having become the beginning point of our resurrection, to renew the vessel that had become useless and broken, in order to deliver us from the tyranny of the devil, calling us to the knowledge of God, to strengthen us and teach us to defeat the tyrant by means of patience and humility. ${ }^{[27]}$

During the Middle Ages there was little progress in the development of Eastern soteriology. Islam swallowed up the entire East, and the Church had to think about its basic survival and not about the development of its theology. The work of mystics carried the weight, such as Simeon the New Theologian (tenth-eleventh centuries) who wrote about the mystical union of man and God and about the deification of the "mortal" nature in Christ through organic union with it, and Gregory Palamas (fourteenth century) who developed the teaching on divine energies (the quintessential Orthodox understanding of the ontological salvation of man: a human being is deified in the course of being filled with the uncreated energies of Christ; mystic illumination by the Tabor light achieved in the experience of Hesychasm, or "holy stillness").

After the fall of Byzantium the Orthodox center gradually flowed to the East, to the Grand Duchy of Moscow, where a new strong center of faith was being formed. In

${ }^{[26]}$ John of Damascus, Tochnoe izlozhenie pravoslavnoi very, part III, 17, <http://www.orthlib. ru /John_of_Damascus/vera3_17.html>, accessed 1 May 2012.
[27] Ibid., part IV, 4, <http://www.orthlib.ru/ John_of_Damascus/vera4_04.html $>$ (accessed 1 May $\overline{2012}$ ). 
addition, a definite juridical influence is noticeable in the East: from the "Eastern Confession of Faith" of Patriarch Cyril Lucaris to the "Catechism" of Peter Mogila and the reforms of Theophan Prokopovich. On the whole, the education at Kyiv Mogila Collegium (Academy) was performed under the prevailing influence of Catholicism and juridicism. Later these influences were taken to Russia where Kyiv professors started systematic education.

6. The rapid growth of Russian theology took place only at the beginning of the nineteenth century. According to scholars of the Russian history of theology, such as Florovsky and Glubokovsky, during the first two centuries of its development (starting from the eighteenth century) Russian theology was deeply influenced by Western juridical theology (this period is also referred to as the two-hundred years of scholastic captivity of Russian theology). Exactly the same thing can be said about soteriology: It is interpreted completely in the juridical categories of ransom and wages for sin. For 150 years (starting from Peter I) theology was done directly or indirectly (in a compiled form) according to Western models. Orthodox Dogmatic Theology (in 2 volumes) written by Metropolitan Macarius (Bulgakov), was one of the main textbooks (almost the official one) on systematic theology. It was written in the language of juridicism and was used in many seminaries during practically all the second half of the nineteenth century. This is why in Orthodox theology the return to the pre-scholastic pattern of the Eastern Fathers was taken by many as a deviation from the true way of Orthodoxy (although this was merely a departure from the way of Orthodoxy that they were accustomed to, "corrupted" by Western influences).

However, starting from the middle of the nineteenth century theology experienced rapid growth with mass translations of Eastern patristic texts into Russian and the beginning of the tendency to move "Forward, to the Fathers!" (according to Florovsky) the situation began to change. More theologians began to accept the Eastern view on salvation, although this transition took place over a long period of time and with a certain struggle.

7. The critical break, the "organic return» took place at the beginning of the twentieth century. It is considered that the first criticism of the juridical theory of redemption was based on the dissertation of Proto-priest Pavel Svetlov (1862-1945), a professor at Kyiv University, and on the thesis of Archimandrite-later Patriarch of MoscowSergius Stragorodsky (1867-1944). In his Master's thesis The Cross of Christ: The Meaning of the Cross in the Work of Christ (1893) Svetlov wrote:

The word of the cross in the teaching of scholastic theology ceases to be comforting for the mind and heart... I will say furthermore that here the scholastically dead and narrow interpretation of the greatest Christian truth nullifies the Cross of Christ in its own way... In scholastic theology all the incomprehensibly great content of the word of the cross is limited to the narrow formula of the teaching of satisfaction. The cross is the bloody price for human sin paid to God's eternal justice. God's greatness, the disobedience of the Creator's creatures distorted by sin, the righteous wrath of God, the endless guilt of man, the undeserved condescension to him on the part of the Ruler of the universe, purchased by the price of the blood of the Son of God-such are the 
ideas around which scholastic thought revolves, crushed by slavish fear before the greatness of God, his endless righteous wrath against people and the eternal guilt of the latter. There is no place for a bright sense of joy and the people's close relationship to God and His Christ in this formula. ${ }^{[28]}$

In 1895 Archimandrite Sergius Stragorodsky wrote his work The Orthodox Teaching on Salvation ${ }^{[29]}$ in fulfillment of the requirements for a Master's degree in theology. In this paper he hardly mentions the objective side of salvation; however, he makes many critical remarks against the juridical view:

The Protestants... turned to life itself and tried to test their conclusions through ithowever, they viewed life from the juridical point of view. Through their teaching they tried to bring peace to the conscience, though they understood peace quite legalistically, in the sense of a feeling of security and impunity for sins committed. Man is afraid of punishment, and here someone points out to him the death of Jesus Christ as such a great, enormous satisfaction for the righteousness of God... But our Church, when pointing out this very side to the sinner (because it is more understandable and closer to the sinner), it does not neglect the other and more encouraging sides of the salvation mystery. It sees in Christ not a suffering tool of propitiation, but the restoration of our fallen nature, the first-fruits of the dead whom He brought out of death, and it calls Him "the Second Adam" (pp. 23-24).

... in the notion of salvation the Orthodox believer puts deliverance from sin in the first place; deliverance from torture and sufferings he will accept as a simple consequence which, in essence, adds nothing to the good received, because it is so insignificant in comparison with blessing in its proper sense (p. 148). ${ }^{[30]}$

Nowadays, Stragorodsky's paper is presented virtually as normative in this area. It offers the Eastern view on salvation as the only correct one, calling the juristic approach totally selfish and unbiblical.

Archbishop Antony (Antonii Khrapovitskii, 1863-1936) who later served as metropolitan of Kyiv and Galicia and as the head of the Russian Orthodox Church Abroad was opposed to juridicism. Nevertheless, the example of Metropolitan Antony reveals how easy it is in one's defense of "divine love" to move from criticism of juridicism to its opposite, and to bring the organic understanding of Christ's work to its (mainly) moral aspects (for this reason the Orthodox themselves criticize it).

Another opponent of juridical understanding was Archimandrite Illarion (Troitskii), a professor of Moscow Theological Academy (a contemporary martyr of Bolshevist times): $:^{[31]}$

It is impossible to agree with the juridical theory of salvation which neglects both the incarnation and resurrection and which knows Golgotha only with its darkened sun, confused creation, trembling earth and splitting stones. This is an alien theory, it is not

${ }^{[28]}$ Quoted by L. Voronov, Dogmaticheskoe bogoslovie, section $21,<\mathrm{http}: / /$ predanie.ru/lib/ book/72469/>, (accessed 1 May 2012).

${ }^{[29]}$ Ibid., section 21.

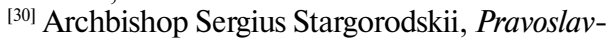
noe uchenie o spasenii (Moscow: Izdatel'skii otdel
Moskovskogo Patriarchata, Iosifo-Volotskii monastyr', Izdatel'stvo "Prosvetitel"”, 1991), p. 264; author's italics. Also available at $<$ http://predanie.ru/ lib/book/77976/>, (accessed 1 May 2012).

[31] See also L. Voronov, Dogmaticheskoe bogoslovie, ibid., section 21. 
from the Church, and it came to the Church's theology only two hundred years ago and became rooted in the Russian Orthodox Church after it had been destroyed by Peter I... Even such ideas as "satisfaction" and "credit," which are foreign to Orthodoxy, find defenders here. In my opinion, to admit these ideas to theology means to twist the pure image of sound teachings about salvation. ${ }^{[32]}$

Many of the Russian Orthodox theologians in emigration spread the ontological view both in the Orthodox East (traditionally its theology always followed Russian theology) and in the West.

In the Orthodoxy of Soviet times, the organic view did not experience development but rather was crystallized and consolidated. (Here it is necessary to mention the works of Proto-hierarch Peter Gnedich, The Dogma of Atonement in Russian Theology and of Proto-hierarch Liverii Voronov, Dogmatic Theology). With the fall of Communism such preservation and accumulation of the organic tradition and its victory gave a new impulse to the development of soteriology.

It is significant that even under the domination of the organic concept the juridical tradition in Orthodoxy has not disappeared completely. Moreover, in our opinion, the organic view will never become decisive in Orthodoxy, because, as any other view, it is limited and cannot contain nor explain biblical soteriological truth in its entirety. Furthermore, as will be explained later, this view contains certain ecclesiological conclusions that are undesirable to traditional churches.

\section{A biblical analysis of Eastern soteriological doctrine}

1. Biblical support for basic soteriological terminology. The Eastern approach prefers the term salvation, because it finds it most appropriate for the concept of deification. The Scriptures contain a sufficient number of passages that talk about the human partaking with God to consider it an important representation of Salvation. However, there are not as many of these passages as theologians of the Eastern tradition would like to have. Moreover, followers of the juridical point of view find them insufficient to talk about the definite biblical advantages of the ontological view of the work of Christ. The texts that are considered by organicists to be evidence for the organic transformation of human nature in Christ and its destiny for eternal deification are the following:

2 Peter 1:4: ... Whereby are given unto us exceeding great and precious promises: that by these ye might be partakers of the divine nature, having escaped the corruption that is in the world through lust; Ps. 82: 6 (parallel with John 10: 34 - 35), "I have said, 'Ye are gods; and all of you are children of the most High.',

Orthodox theologians claim that this teaching has a deep biblical foundation that goes beyond the two quotations above that express the idea in a clear way. They quote other passages of Scripture such as Ex. 34:30 (about the shining face of Moses as a clear sign of deification); Ex. 7:1 (Moses became "god" for Pharaoh). They see more evidence

${ }^{[32]}$ Quoted by L. Voronov, Dogmaticheskoe bogoslovie, section $21,<$ http://predanie.ru/lib/ book/72469/, (accessed 1 May 2012). 
in Christ's Transfiguration (Mt. 17:1-9). In this same sense (even a teleological sense) they quote Col. 1:19-20:

For in Him all the fullness of God was pleased to dwell, and through Him to reconcile to Himself all things, whether on earth or in heaven, making peace by the blood of his cross.

In the ontological sense, the following passages are also cited: 2 Cor. 8:9, Heb. 2:10, 4:15, Rom. 6:6, 7: 4-6, 23-25, Rom. 8:2-4, 2 Cor. 5:14-15. In the organic understanding (as a united Body of humanity) the following passages are interpreted: Rom 5:1221, 6:1-11, 1 Cor. 15:45-49, Eph. 2:5-7, Heb. 7:4-10. Orthodox organicists criticize the preference for juridical terms over organic ones:

... the word Redeemer is present in the Old Testament only, but there is no mention of it in the New Testament. In the Gospels we see the word redemption only twice (Matthew 20:28; Mark 10:45). A number of times it is used in the Epistles, and the reason for that is quite obvious. The Epistles were written to Christians from Jewish and Gentile origins, the minds of whom were fully saturated with a juridical, "legalistic" understanding of religion. Therefore, to make the mystery of Christ's incarnation more understandable, the apostles often used the terms to which [their hearers] were more accustomed. ${ }^{[33]}$

From the point of view of evangelical-Protestant understanding, it is inappropriate to talk about a direct preference for one term over another (unless the term is salvation, although in the general sense of the redeeming work of Christ, not in the sense that organicists give to it). Christ's salvation is immeasurable in the ontological sense and multi-dimensional in our approaches to its explanation. Therefore, to do justice to ontological understanding, we should properly exercise the complementary juridical approach when explaining the work of Christ, and the juridical terms of redemption and justification, especially taking into consideration the rich biblical soil in which they were planted.

We cannot agree that the apostle Paul mainly used juridical terms because he was writing to "former Gentiles in the West." There are epistles that were written by him to the East, where the minds of the people were saturated with images of physical unity with deity, with the mysteries of "deification." Organicists emphasize that in New Testament times the juridical notions of judgment and guilt receded into the background, totally yielding their place to the revelation of the loving God. However, it is impossible to separate God's love from His justice, as He displays His justice and wrath when His love sees a violation of God's sovereign rights (e.g. Jesus' anger at the Pharisees) or when $\sin$ infringes upon and violates His creation (God's wrath as a reaction of God's love to the "belittling" of its rights). It can be said that we make a distinction between God's justice and His love because of our very imperfect knowledge about Him; in Eternity these two notions merge together into one attribute, namely God's

${ }^{[33]}$ A. I. Osipov, Lektsii po dogmaticheskomu bogosloviu za 4-i kurs MDS, lecture 10, <http:// searchebookonline.com/book_586.html та http://orthtexts.narod.ru/>, (accessed 2 May 2012). Note that Professor Osipov's lectures are notes of audio lectures and therefore may be a somewhat inaccurate source; however, they are used by the author as a vivid characterization of modern organicism (see below), of which Osipov is a representative. 
holiness. When the juridical component is taken away, we lose the correct understanding of God's love.

For a human being the fear of God ("the beginning of wisdom," Pr. 1:7) is the beginning of love. The true worship of God includes both the fear of God (e.g. the seraphim who cover their faces before God in their sacred trembling, Isa. 6:2-3) and love for Him. It is written about Christ Himself that He was "filled with the fear of God" (Isa. 11:2-3). Jesus does not only demonstrate perfect love to God, but perfect fear of Him as well. He accomplishes not only salvation as a deed of love, but also accomplishes the judgment of God. If the "line of John" talks about God's love only, why was the Book of Revelation written by John-the book that talks about the wrath of God and His judgments?

2. Selective hermeneutics. It is not as if different confessions have never seen those Scripture passages that support an alternative understanding of the work of Christ. It is merely that they each reside in their own soteriological "matrix" which does not allow them to see the rightfulness of other interpretations; that is why they are doomed to one-sidedness within in the framework of their soteriological "system of coordinates."

Let us observe it in the example of a well-known passage of Scripture, Isa. 53:3:

He was despised and rejected of men; a man of sorrows, and acquainted with grief: and we hid as it were our faces from him; he was despised, and we esteemed him not. ${ }^{4}$ Surely he hath borne our grief and carried our sorrows: yet we did esteem him stricken, smitten of God, and afflicted. ${ }^{5}$ But he was wounded for our transgressions, he was bruised for our iniquities: the chastisement of our peace was upon him; and with his stripes we are healed.

From the point of view of the classic juridical interpretation, this passage means that Christ took upon Himself our damnation for sin and carried our guilt for sinthat is why we are now imputed with His righteousness. From the point of view of the organicist interpretation, this passage has the following meaning: Christ took upon Himself our nature with all the consequences of the Fall in order to heal it in Himself. He truly experienced sicknesses ${ }^{[34]}$ as consequences of the Fall; He took this nature to the cross, healed it in His death, and returned it renewed in resurrection.

As we see, the discussion is not merely transferred from the realm of soteriology to hermeneutics. Our understanding depends not only on certain rules of interpretation, but, first of all, on basic approaches which are accepted a priori and which influence our hermeneutical principles. Based on this statement, it is impossible to criticize Orthodox believers for their "few passages in support of an ontological view." Taking into account their soteriological "system of coordinates" one can agree that, indeed, "one can see figures of deification in many Scripture passages." ${ }^{[35]}$

${ }^{[34]}$ In our opinion, the question of whether Christ could literally suffer illness remains open in evangelical theology. The juridical interpretation, in our opinion, tends more to a symbolic understanding of this Scripture passage (sickness as a curse or guilt for sin).

${ }^{[35]}$ Unfortunately, this applies to any attempts to prove the rightness of one's personal understanding of the Scriptures. There is a nanve Protestant belief that all disagreements between confessions can be canceled if the Scriptures will be interpreted "literally" or simply by "studying the Bible with open eyes." The Orthodox warn that the Scriptures have to be understood with a 
3. Means of salvation. The incorporation of God's grace. The organic vision opens up interesting perspectives for the mystical understanding of the Church as Christ's Body. According to it, by His deed Christ redeemed not only a separate group of elect but the Body of humanity as a whole. He received human nature in Himself and in it (supporting an indissoluble connection with all of human nature as a whole) $\mathrm{He}$ freed all humanity from the presence of sin and the consequences of the Fall:

Therefore as by the offence of one judgment came upon all men to condemnation; even so by the righteousness of one the free gift came upon all men unto justification of life (Rom. 5:18). Knowing this, that our old man is crucified with him, that the body of sin might be destroyed, that henceforth we should not serve sin, ${ }^{7}$ for he that is dead is freed from sin" (Rom. 6:6-7).

Here the organic theory of salvation is certainly true. However, in our opinion, there can be an unexpected conclusion for traditional churches: since Christ, on the ontological level, has completed in Himself the restoration of the united Organism or human nature, then salvation belongs to the whole joint Body of humanity and not only to a particular closed society.

Therefore:

1. Every human, potentially, inherits the deed of Christ simply by the fact of his or her birth into the Body of Adam-Christ, and can accept salvation, which is his by right, through the immediate use of the gifts of the Holy Spirit.

2. Faith is an instrument of our salvation. (The traditional churches accept this as well). All ministry and teaching should serve the one goal of developing faith as an instrument of connection with the saving Christ: "Received ye the Spirit by the works of the law, or by the hearing of faith?" (Gal. 3:2). Every human can freely come directly to the Lord (taking into account the unity of the saving Body of humanity).

3. A particular monopoly of the Spirit (traceable in all Christian communities but, in particular, in traditional churches) in our opinion, has no biblical basis. «The wind bloweth where it listeth» (John 3:8), and not only where and in the way it is ordered to by specific confessions.

\section{Doctrinal analysis. Benefits of the organic approach}

1. History of theology as a significant factor. In favor of this understanding is the fact that it belongs to the early Church. Nowadays the organic view is more typical of the Orthodox faith. The Eastern soteriological model has the following important advantages:

1. It presents a reasonable explanation of how our sin became the sin of the Lord. Sin as a phenomenon (the guilt for sin or personal sin) is inseparable from human nature (environment or cause for sin which produces individual acts of sin).

churched, synodic mind. There is a specific "hermeneutical tautology": the Scriptures can be understood only by a "synodic deified mind," and a mind enlightened by the Church, to which the inner spiritual sense is opened, can perceive the images of deification in different Bible passages etc. Criticism does not work-it is an endless circle in which every confessional group sees its own truth. 
2. The theory provides a good foundation for the juridical understanding of salvation and redemption (as the establishment of right personal relations with the Father). Punishment for sin requires not only the imputation of Christ's righteousness to us, but also liberation from the sinful nature itself, i.e. the elimination (or transfiguration) of the universally corrupted human nature.

3. Restoration of the unified Body of humanity is proved by the general Resurrection of all people; it is an impressive confirmation of the organic theory. However, personal salvation requires personal relationships (i.e. personal faith for changing the direction of the will) with the Lord in the unified Body of humanity.

2. Question of guilt and sin. Ontological understanding of the nature of sin. In Eastern theology the term "original sin" has the following meanings:

This is not the personal sin of the ancestors (which, in contrast to original sin is called generational sin); this is the inherited deep corruption of human nature, mortal and perishable; it is a distorted image of God as a consequence of the disobedience of the first humans, which has a constitutive and not a spiritually moral character. Given that none of the descendants participated in the sin of the ancestors either consciously or willingly, there is no other human who would bear the moral responsibility for this original corruption. ${ }^{[36]}$

The concept of the imputation of the ancestors' sin to their descendants plays an important role in juridicism. However, it is rejected in the Orthodox faith. From the ontological perspective one can talk about imputation only in the sense of the sinful nature of the ancestors which was transferred to us, but not on any account in the sense of the guilt for sin.

The Eastern view gives a good explanation of the problem of how the sins of all people became the sin of Christ (in other words, how He "took upon" Himself our sin). The point is that juridicism significantly obscures the issue of the unity of human nature (all humanity, including Christ, is a single Adam "multiplied"). It clearly affirms only that Jesus is truly man, and indirectly that $\mathrm{He}$ is a descendant of the same sinful Adam. It postulates that His nature is sinless. Why and how does a sinless man takes upon Himself the guilt for someone else's sin or have to pay for it? The simple explanation that "Christ in His human body pays another's debt" does not pass scrutiny. Followers of the ontological understanding who continuously criticize juridicism, have always called legal nonsense the statement that someone can (and will be) sentenced to death in place of another person. If the sin is, first of all, guilt then in what way can someone else's guilt be put, imputed or poured out on another person, the guiltless one? When and how was it done-at Jesus' birth, baptism, or at Golgotha?

For that matter, how can one separate humanity's guilt from its sinful nature? The guilt by itself is something ephemeral (how can one pay for the guilt of sin without the sinful nature which produces sin?). This is why the organic view, which does not divide $\sin$ (as a defect or guilt) from human nature, but takes them in their totality, takes a strong stand in anthropology and the concept of sin.

${ }^{[36]}$ A. I. Osipov, Lektsii po dogmaticheskomu bogosloviiu za 4-i kurs MDS: Lektsiia 9-9.1, Poni- atie grekha, <http://searchebookonline.com/ book_586.html $>$ (accessed 2 May 2012). 
3. The theory is focused on man's nature, and not on the question of human nature's sinfulness. The organic interpretation asks the right question: What is the meaning of payment for sin if man's sinful nature remains unchanged? Can it be that Christ simply canceled guilt but left the sinful nature alive? Organic theory truly points out that the Lord not only simply canceled the consequences of sin, but neutralized the cause of sin: the sinful nature:

...by His sufferings Christ not only restored in Himself human nature, but this restoration did not remain lifeless - the Resurrection followed, i.e. He has destroyed death by His death. Better to say that by the death of the old man, by the death of defective human nature, the resurrection of the new man became possible. The old one is killed; everything that is old is destroyed. The new, restored, and healed human nature rises from the dead, and we see it in the resurrection of Christ. ${ }^{[37]}$

In our opinion the juridical interpretation does not give a clear exposition of the question of the unity of Christ's human nature with all of humanity (how the inherited guilt of humanity became His guilt).

The logic of the organic approach is as follows: ${ }^{[38]}$ If Christ received a sinless nature from Mary, then in what way could the consequences of the defect (or guilt) of humanity apply to Him? What could He do for us then, based on His nature? If God the Word took up an undamaged (i.e. guiltless) nature (becoming like "Adam before the Fall") then a question remains: What has been done in this human nature? What is the significance of the work of Christ? If His nature did not bear the consequences of Adam's corruption, then what is it that Christ has achieved? There is no place for the "organic deed"- there is nothing to heal.

Juridicism answers that the sin of the ancestors called forth the lawful anger of God, the universal state of sin and guilt. Guilt as the burden of unpaid, endless debt to God's holiness and justice is placed on all the descendants of Adam. Therefore, God the Word received an uncorrupted and pure nature and He suffered in it by His own will (or by the will of the Father), and not because this nature bore in itself the consequences of the original corruption and organically had to suffer. He took upon Himself the guilt for our sin exclusively by His own will (not because He had to submit to the universal law of Adam's nature).

In that case, why is the sin of humanity is imputed to Christ? It is considered that the juridical interpretation, if not sidestepping the examination of how the sin of humanity was passed on to Christ, simply assumes as its basis the fact of God accepting Christ's sacrifice, which fully satisfies His justice without any investigation of how it was done. Having suffered in this body, Christ could voluntarily satisfy God's justice (bring the sacrifice of atonement).

Undoubtedly, there is a grain of teleological truth in it: no one can tie God to any definite causative motives of behavior (i.e. to put eternity in frames of causality). Christ suffered completely voluntarily. Hence, at the same time, the man Jesus had to be sub-

${ }^{[37]}$ A. I. Osipov, Lektsii po dogmaticheskomu bogosloviu za 4-i klass MDS: Lektsiia 13, <http:/ /orthtexts.narod.ru/ и http://orthtexts.narod.ru/ 13_Voskreseniye.htm> (accessed 2 May 2012).
${ }^{[38]}$ Ibid., Lektsiia 11, <http://orthtexts.narod. ru/ и http://orthtexts.narod.ru/11_vidy_greha. htm $>$, (accessed 2 May 2012). 
jected to the universal law of human nature, without exception. Certainly, this is a manifestation of the antinomy of God's incarnation, but organic argumentation seems to be more logical here: Christ came first of all to produce the internal healing of nature in Himself and not simply for an external act of redemption.

4. Salvation is accomplished in the Body of humanity, or-through a man; the personal participation of humanity in its own salvation. Besides the general, organic weaknesses of the juridical approach there is another practical shortcoming, namely that Christ is incarnate and saves people as if without their participation. The Catholic Church has experienced the shortcomings of the juridical approach as well, although in a slightly different way than the Protestants. The semi-Pelagianism of the scholastics of the late medieval period was a distinct form of juridicism, with their teaching that salvation is based on a definite system of juridical relationships. A man himself takes the "first step" (albeit the smallest-trying as best one can) and in response God sends His saving grace. The teaching of the Magisterial Reformation on Salvation as the exclusive work of Christ is a predictable response to this deviation. However, the Reformers noticeably moved the accent of Salvation from the juridical, anthropocentric to the exclusively theocentric (the complete denial of man's will and human participation in personal salvation).

However, according to the ontological approach, salvation was completed by Christ precisely in the Body of humanity. That is why man took (and must take) part in his or her own personal salvation. The Eastern approach views the history of humanity as a long road of preparation (God's training) aimed at the capability of humanity to receive God "in itself." From this point of view, Mary stands at the end of this road as a unique concentration of human effort (or faith development), as the first earthly human who became capable (worthy) of receiving God's grace in herself (accepting the invitation of the incarnation with all her heart), and giving God the Word our nature. ${ }^{[39]}$ Having agreed by her own free will to the incarnation, humanity in the person of Mary made it possible for the God-Man to come into the world. This ontological eternal event, infinite in its consequences for all people, required the preparation both of the whole of humanity (training by life and law, the development of faith and freedom for thousands of years), and Mary (as an independent representative or as God's instrument who by her free will agreed to become the Savior's Mother). This infinitely elevates human nature, showing its true meaning in the eyes of God. Such an approach illustrates the immeasurable weight of creation, making it a participant both in its own salvation and in the regeneration of all created things. It is not a question of sinful creation saving itself by its own strength, for God Himself accomplishes this ontological soteriological deed through man (or "humanity completes its salvation by Christ or in Christ"). That is why the cult of Mary from this point of view is connected precisely with the recognition of the infinite soteriological significance of human nature (which is now the nature of God Himself), of creation itself, of which we are an organic part.

${ }^{[39]}$ Already Justin Martyr and Irenaeus in the second century drew a parallel between Mary and Eve: "Mary is the last Eve" (on the analogy of "Christ is the last Adam"). 
(John of Damascus said, "I do not cease to honor creation for through it ["by means of it"] I received salvation." $)^{[40]}$

5. The ontological position correctly places the emphasis on the question of Christ's sacrifice. The perception of the work of the Lord exclusively as a "sacrifice" and a "ransom" raises a logical question: To whom was the Sacrifice on the Cross made? Juridicism (by analogy with Old Testament sacrifice) tends to think that the redemptive sacrifice of Christ was made to the Father. In the East the Council of Constantinople (1156) condemned the idea that the Sacrifice was given to the Father only, and it confirmed the teaching of Gregory of Nazianzus that Christ was the "Sacrifice, and also Bishop, the Priest, but also God," and the teaching of Simeon the New Theologian that "Christ sacrificed Himself in the body for the Godhead the Father, the Son Himself and the Holy Spirit." "[4] Gregory the Theologian has an interesting argument:

It remains to examine the question and the dogma to which many have failed to give attention, but which for me demands examination. To whom and for what was this outpouring of blood for us-the blood of the great and most holy God and Priest and Sacrifice?... And if the price of redemption is given to no other than the one who holds the power, I ask: to whom and for what reason was such a price exacted? If it was to the evil one, then how insulting it is! A bandit receives the price of redemption, receives it not only from God, but God Himself, for his own suffering takes such a limitless price that it would be just to have mercy on us! And if it is to the Father, then, first of all, how is it done? We were not in captivity to Him. Second, for what reason was the blood of the Only Begotten accepted by the Father, Who did not accept Isaac when he was brought by his father, but was replaced by the sacrifice of a ram? Or is it apparent from this that it is acceptable to the Father, not because He demanded it or needed it, but for the sake of house-building and therefore that man needed to be made holy by the humanity of God, so that He Himself would rescue us, subduing the tormentor by strength and bringing us to Himself through the Son. ${ }^{[42]}$

This means that Christ's sacrifice was, first of all, a sacrifice of love and obedience which was given to the Holy Trinity for the sake of God's house-building, that is, for the restoration of creation in its eternal glory.

\section{Limitations of the organic approach}

1. Observations on the traducational model of the soul's origin and its application. As a rule, this view is based on the traducational (traducatio, meaning origin, heritage) approach to the soul's origin. However, in spite of it apparent value, the view has little support in Christianity. For instance, Catholics (as well as many Protestants) hold creationist views (in their dogmatics this is a first-order dogma). Though the traducational

${ }^{[40]}$ Pervoe slovo protiv poritsaiushchikh sviatye ikony i izobrazheniia quoted by John of Damascus in Tri slova v zashchitu ikonopochitaniia (St. Petersburg: Izdatel'stvo “Azbuka-klassika," 2001), p. 138.

${ }^{[41]}$ According to A. I. Osipov, Lektsii po dogmaticheskomu bogosloviiu za 4-i klass MDS: Le- ktsiia 12, <http://orthtexts.narod.ru/ и http:// orthtexts.narod.ru/13_Voskreseniye.htm $>$, (accessed 2 May 2012).

[42] Gregory Nazianzus, Sobranie tvorenii, 2 vols. (Minsk: Kharvest; Moscow: ACT, 2000), vol. 1, Word 45 "Na Sviatuiu Paskhu,” p. 831. 
view prevailed in the Church of the patristic period, it is accepted in Jewish rabbinical thinking and has a strong biblical basis (Adam as the Head of the organism; the integral theory of human origin). That is why, in our view, this observation cannot be an essential weakness; the traducational approach (under specific premises ${ }^{[43]}$ ) can be positive.

2. Contradiction concerning the issue of which nature Christ has taken on. Eastern soteriological doctrine has to overcome one critical problem of the organic theory. From the work of Christ as the correction of corrupt human nature it follows that Jesus has done this work in His own body. The question arises: which Body did Jesus receive at His coming? How has He destroyed Adam's nature? Christ committed no personal sin; this is an absolute teaching of the Bible: "For he hath made him to be sin for us, who knew no sin" (2 Cor. 5:21). How could He take on all the fullness of the "sin nature" in order to destroy it, while He Himself remained sinless? The followers of the organic position answer this question in two ways:

1) Christ took up a sinless nature, however with the consequences of the Fall. His nature was free from original sin, but Jesus carried in Himself the consequences of the damaged nature: He was tired, hungry, and sick (all these are the consequences of Adam's nature). However, it is difficult to imagine how one can receive a nature "cleansed" from original sin and, at the same time, suffer from the organic consequences of its corruption (this is a "juridical element in the organicist position": the imputation of consequences without the nature).

2) Christ took up human nature in all the fullness of its corruption, including original $\sin$ (extreme organic approach). Without committing any personal sin, He carried this nature throughout all His life and crucified it on the cross, destroying "sin by death." What was "born" in Adam at the Fall was destroyed by Christ at the cross. Logical negation: it is impossible to imagine Jesus in "sinful nature,"-this can lead to blasphemy, counting God's Son as a "sinner." Common justification: on the contrary, this is the mystery of the Son's holiness and glory-being in our nature (corrupted by the Fall), He never sinned personally; He has eliminated the original defect of Adam and resurrected human nature in its sinless state:

...is there any basis to say that Christ took upon himself precisely this corrupted nature; is that not a dreadful blasphemy, that the All-holy God is united with corruption, that is, with the sin nature?... Only personal sin is the sin that sullies a person, evil corrupts, but the fact that a person was born with an inclination to something or other does not corrupt; it is only corrupting when a person with that inclination agrees and begins to act in accordance with it, but the inclination itself does not corrupt. And so it is very important that original sin as a defect is not that which corrupts a human being; it is a constitutional imbalance; only personal sin is sin in the full sense of the

${ }^{[43]}$ If we suppose that human souls are not simply "inherited" by a human from a human without God's participation; in that case, man himself acts as the creator of a definite spiritual substance, but if we accept that the creation or inheritance ("reproduction") of souls is done by a single Creator, not only from within, but through the single nature of humanity (this approach unites the traducational and creationist approaches). 
word. Everything else is a defect. Now it is clear why the apostle Paul could say so boldly, "He who knew no sin became sin for us." ${ }^{[4]]}$

According to the author's limited information, the second approach is advancing, but it is still in the minority in the Orthodox faith. Nevertheless, it is confessed by wellknown Orthodox apologists and missionaries, such as Professor A. Osipov (Moscow Theological Academy) and his student Proto-deacon A. Kuraev:

If in Christ human nature did not experience healing, then there is no difference between the Humanity of Christ before the Resurrection and after the Resurrection... but if we suppose that the Savior took up that human nature which it had become after the Fall and by His deed He raised it even higher than it was in Adam before he sinned-only then are there no "irrelevant" pages in the Gospel. ${ }^{[45]}$

It should be noted that this is an endless antinomy: on the one hand, Jesus did receive the fullness of our nature (otherwise, how could Redemption and punishment for sin take place?); on the other hand, He was completely holy and sinless. Nevertheless, the great power of organic theory, in spite of some ambiguity over the issue of the nature of Christ's body, is in its correct understanding of the essence or mechanism of the saving work of Christ. The followers of organic theory point out that our interpretation of Salvation depends on our correct understanding of the question of which nature was taken up by Christ.

In our opinion, it is better to stay on the verge of antinomy: 1) Christ is completely holy; He committed no sin and His sacrifice is exclusively a payment for our sin:2) $\mathrm{He}$ completely assimilated our Adamic nature, but without personal sin; He was absolutely united with us, therefore His sacrifice is our payment for sin. In other words, the Word descending to our nature sanctified it by Himself. ${ }^{[46]}$ In this way we can avoid the extremity of Catholicism, which has to extend Christ's holiness to His Mother, in order to explain His sinlessness (Mary's pre-purification by the power of the Holy Spirit at her conception), as well as the extremity of Orthodox organicism which occasionally interprets the body of $\sin$ (Rom. 6:6) as sinful body.

3. Denial of the juridical aspect of salvation. The Scripture clearly teaches about Christ as the Sacrifice for sin. Moreover, juridicism was typical not only of Roman and Western thinking (as the followers of this theory insist), but also of the Jews-the whole Law is built on images of "guilt - sacrifice - reconciliation." The organic interpretation has its logic: Christ by means of Himself has destroyed the "body of sin"; therefore all questions about "payment for sin" were eliminated by themselves - the "old man" was destroyed. However, extreme support of this theory leads to total rejection of the prob-

${ }^{[44]}$ A. I. Osipov, Lektsii po dogmaticheskomu bogosloviu za 4-I kurs MDS: Lektsiia 11, <http:/ /orthtexts.narod.ru/ та http://orthtexts.narod. ru/11_vidy_greha.htm>, (accessed 2 May 2012), author's italics.

${ }^{[45]}$ Deacon A Kuraev, "Okhotnichii azart vmesto bogosloviia," in O nashem porazhenii (St. Petersburg: Svetloiar, 1999), p. 496; also available at $<$ http://kuraev.ru/index.php?option= com_ content\&task $=$ view\&id $=23 \&$ Itemid $=0>(a c-$ cessed 2 May 2012).

${ }^{[46]}$ For instance, this view is close to Millard Erickson's: "It is quite possible that the influence of the Holy Spirit was so powerful and sanctifying that no guilt or depravity was passed from Mary to Jesus." See M. Erickson, Khristianskoe bogoslovie (St. Petersburg: Bibliia dlia vsekh, 1999), p. 645. 
lem of sin as guilt and the necessity of reconciliation. (God is Love and He forgives everyone, therefore Christ did not reconcile God with humanity, He corrected the human and in that way has reconciled him or her with God.) In our opinion, here we are dealing with a specific moralistic deviation in the organism. Based on this consideration, all Bible passages that clearly teach about redemption and reconciliation must be interpreted by organicists in the corresponding "organic" sense. They have to treat the writings of the Church Fathers in the same way: all the "juridical places" of the Fathers are read through "organic glasses." Every now and then, the war with juridicism in theology leads to its complete denial:

In my opinion, the juridical element can be completely avoided both in the area of belief, and in the area of moral teaching. ${ }^{[47]}$

That belittles and narrows down the understanding of Christ's sacrifice; it distorts some of God's attributes to accommodate others (justice and holiness are "sacrificed" to love and mercy; a "left deviation" toward love away from God's righteousness and His anger).

This doctrine ignores the juridical aspect of Christ's sacrifice and it does not agree with those Bible passages where the idea of sacrifice-payment for sin plays a significant role (or they interpret them in the moral-organic sense). There are a number of biblical texts that better fit the juridical theory but they do not find a complete interpretation in the ontological view. The issue of right lawful relationships of creation with the Creator is not merely a shortcoming of "Western thinking" (criticism of organicists) but a sober, biblical approach to personal relationships with an absolutely holy and just God. ${ }^{[48]}$ In our opinion, the ontological understanding overlooks this essential aspect of the relationship between intelligent creation and the infinite holiness of the Father. As mentioned above, the relationship between sinful creation and such a God is built not only on love, but also on the fear of God, and this is not a selfish fear, but a holy fear which is named "the beginning of wisdom" (Prov. 1:7). As we see, organicists fully accept the biblical truth which states that, "Herein is love, not that we loved God, but that he loved us, and sent his Son to be the propitiation for our sins" (1 John 4.10). However, those passages which tell us: "Therefore, since we are receiving a kingdom that cannot be shaken, let us be thankful, and so worship God acceptably with reverence and godly fear: for our God is a consuming fire" (Heb. 12:28-29), are subjected to a moralistic interpretation. According to the evangelical juridical understanding, it is impossible to establish loving relationships with God without the initial restoration of His glory (as justice), and without granting humanity His righteousness; this is the basis on which we have relations with Christ and receive the gifts of the Holy Spirit. For organicists, these questions turn into a certain kind of "formality" - the logical and irrelevant consequence of human nature's deification performed by Christ.

${ }^{[47]}$ Quoted by L. Voronov, Dogmaticheskoe bogoslovie, Razdel 21,<http://predanie.ru/lib/book/ 72469/> (accessed 1 May 2012).

${ }^{[48]}$ Author's note: Does the persistent denial of juridicism explain one of the reasons why the so called "Orthodox countries" never in their whole history created a constitutional state? The loss of right juridical relationships with the $\mathrm{Fa}-$ ther leads to the loss of right relationships in society. 
4. Underestimation of the universal unity of the Body of Christ. In our opinion, one important and unexpected fact of this point of view is that from the doctrine of the organic healing of our nature in Christ follows a very unpleasant conclusion for traditional churches concerning the universality of the Body of Christ. If Christ died in our nature corrupted by sin, then His death is the death of all the totality of human nature. How, then, can Orthodox believers talk about regeneration as "union with Christ in the sacrament of baptism" and of "tasting Christ in the mystery of the Eucharist," ${ }^{[49]}$ when this mystery of the Eucharist took place when Jesus, by the fact of His incarnation, took all the totality of human nature in Himself, entered humankind, adopted the nature of the first man, became the "last Adam" and has again united all humanity in one organism? Therefore, His saving deed is organically and immediately extended to all the Body.

We get the impression that it is the organic aspect of the Eastern vision, evident in the teachings of the Fathers, that is "darkened" in contemporary Orthodox theology turning it into an irrelevant addendum to the teaching on the only saving church which is the only place where one can receive the restored essence of the Lord through the sacraments.

We note that potentially Christ's nature as the healed nature of Adam can be adopted by everyone right from birth into the united Body of humanity. Independent of confession, everybody has equal access to this nature already by the fact of belonging to Adam's kind-salvation is not any closer to us in the Orthodox Church than it is in any other church that confesses belief in the Trinity and the God-man.

Orthodox believers will never accept this conclusion; therefore we need not expect a) that Eastern theology will accept fully the consequences of their organic vision and, as a result, b) that there will be a complete victory of the ontological-organic theory of Salvation in Orthodoxy.

\section{Conclusion: Understanding how a believer becomes connected to the Body of Christ is the basis for the unity of soteriological and ecclesiological worldviews}

1. In order to be saved every person has to join the saving Body of Christ. How is this union achieved? In our opinion, in both ecclesiological movements (juridical and organic) one can sense a peculiar separation of the Head from the rest of the Body. This is a consequence of the antinomy of Salvation: Christ has accomplished the salvation of mankind but it was done in His own Body. How much is this Body of Christ is united with the whole Body of humanity? Logically thinking, it is still united today:

Since it was from no other composite than ours that God took up flesh, exalted together with the Deity by resurrection, therefore as in our body the act of any one of the sense organs leads to the apprehension of everything connected with that organ,

[49] The author is not trying to depreciate the traditional understanding of the Eucharist which states that at the moment of the sacrament the literal acceptance of the Lord's nature takes place; he merely states that twenty centuries ago
Christ completely joined humanity in one continuous Eucharist, and that this union is potentially real for everyone who is able to receive this eternal truth by faith. 
so it is that inasmuch as all existence is as if one living being, the resurrection is extended to everything, according to the indivisibility and unity of the being, imparted from the part to the whole. ${ }^{[50]}$

From the ecclesiological teachings of Christian communities it follows now that it exists as if independently from the rest of the whole Body. It is as if "by itself" and the connection with it is established and supported by faith (Protestantism) or through sacraments (through the sacral life of a believer-traditional churches). Grace brings a person to the Church and joins him or her with the Body. The Body of the ChurchBody of Christ is presented as if "separated" from the rest of the unified Organism. The understanding of the organic unity of Christ with the whole Body of humankind is lacking.

There are two central passages in the New Testament that talk about unity between Christ and the Body of humankind (analogy Adam-Christ): Rom. 5:12-21 and 1 Cor. 15: 21-57 (especially vv. 42-49). According to the organic interpretation of these texts Christ acts not only as the representative of humankind, but He Himself can be viewed as the whole of the Body who encompasses the fullness of human nature. All the gifts of Salvation are real right now; however, for us they are still potential, since their adoption depends on our awareness and the free choice of our will. Nevertheless, they do belong to us for two reasons: 1) our birth in the body of Adam 2) Christ's birth and His redemption of this same body. This unity and restoration of all human nature is clearly confirmed by the general resurrection of all humanity-both righteous and sinful. The sinful have rejected the gift of salvation, but still they will not avoid the general resurrection by the right of belonging to the body of Adam-Christ (although they will come to the judgment place in the bodies of condemnation).

2. Therefore, there is a particular misunderstanding of how grace is spread in the body of humankind and it makes every Christian community withdraw within the framework of its "gracious exclusivity."

It looks strange, in our opinion, first of all among Protestants, since they arrived rationally at the understanding of general use of the gifts of the Spirit simply by faith. However, surprising as it may be, every Protestant community as a whole, as well as traditional churches, considers itself the only one that is getting saved. Again, at least for traditional churches such a position is historically and canonically validated (to some degree). Protestants did not make use of the heritage of organic theory, although on the biblical ("intuitive") level they understood and utilized the truth concerning each person coming directly to Christ by faith without any ecclesiological or sacral restrictions. Even more surprising are their claims to soteriological priority (not only over the traditional churches but especially over related evangelical movements). Thus narrowness of mind and excessive dogmatism do not allow them to see truth more broadly in order to extend its influence over others (at least, not to refuse them their right to be named Christians and to claim salvation in the framework of their own confession).

${ }^{[50]}$ Gregory of Nyssa, "Bol'shoe oglasitel'noe slovo, 32, <http://agios.org.ua/wiki/index.php/
Григорий_Нисский._Большое_огласительное_слово>, (accessed 2 May 2012); author's italics. 
3. Each community claims that their church is the only center of Christ's Body (evangelical Protestants claim the community of those who were directly regenerated by the Spirit; traditional churches claim the presence of the Spirit in the one apostolic Church). Regardless of which side of the saving work of Christ is stressed, there is a peculiar desire to "monopolize" this work for themselves only, to become the exceptional "heir-distributor" (exclusive purveyor) of spiritual goods through the claim of ownership of the whole Body in their part of the one Church.

Each confession produces its individual view of personal salvation according to its limited understanding of the saving work of Christ. Nevertheless Protestants, it seems, do not fixate on the notion of one unified saving church; however, they have a tendency to make personal salvation subject to following the "salvation only" teaching of a separate (of course, their own) community. However, as was said above, the organic soteriological approach does not give any basis for such an understanding, not only for traditional churches, but for any other churches as well.

4. If Christ's body truly has no more connection with the rest of humanity and His saving gifts are given apart from Christ (or out of connection with the united Body of the humankind), then, obviously, one must dedicate one's life to searching for the only saving church, the visible true community taking part in the Body, which is the only one where the Spirit is working and where the fullness of Christ's saving grace is present. The Church, in which (thanks to the one salvation doctrine) or through which (thanks to it being the only place where saving grace is given) one can communicate with the saving Body of humanity. Nevertheless, as was explained above, the body of Christ continues to remain an organic part of the unified Body of humanity; therefore all the gifts of the saving act of Christ belong to the whole Body.

From this point of view the Church is a community of people who have realized their unity with Christ in the unified Body of humanity (not a closed "select" society, proud of its confessional membership). Knowing the truth about organic inseparable union between us and the Lord in the united Body we have to be responsible both for our confessional community (thanks to which we fulfill our ministry to the whole Body), and for the rest of the Body, disunited by sin as well as multiple prejudices of humankind. Having realized the truth of our organic union with the Lord, we can consciously build our spiritual life based on the literal reality of the following principle, "which is Christ in you, the hope of glory" (Col. 1:27). 